\title{
Anaerobic Digestion of Microalgal Biomass Acutodesmus dimorphus (Turpin) P. Tsarenko as a Substrate for Biogas Production
}

\author{
Natalia Głowacka ${ }^{1,2 *}$, Ján Gaduš¹, Ján Slobodník ${ }^{3}$ \\ ${ }^{1}$ Department of Regional Bioenergy, Faculty of European Studies and Regional Development, \\ Slovak University of Agriculture, Nitra, Slovak Republic \\ ${ }^{2}$ Environmental Institute, Koš, Slovak Republic \\ ${ }^{3}$ BioRent, Sládkovičovo, Slovak Republic
}

Received: 6 July 2017

Accepted: 10 September 2017

\begin{abstract}
It is only a matter of time for when fossil fuels will not be accessible at low cost, which is the major reason why it is obligatory for researchers to find an alternative feedstock to replace the currently stable position of fossil fuels in the world. The objective of this study was to review the potential of green microalgae Acutodesmus dimorphus (Turpin) P. Tsarenko, which can become the replacement for the commonly used raw materials for anaerobic digestion. Recent scientific focus has targeted the research of alternative renewable energy sources. Green microalgae are the alternative raw material for generating bioenergy due to high photosynthetic efficiency. Many modern solutions for cultivation systems of microalgae, maintenance, and harvesting techniques are currently under development all over the world. It is necessary to find the proper technology for algae cultivation and that will deal with all environmental and economic issues. The innovative process can provide the prerequisite scale for increasing commercial use of bioenergy from microalgae. The interim research results presented in this study show that microalgae are a suitable alternative material for biogas production in the method of anaerobic fermentation.
\end{abstract}

Keywords: microalgae, biomass, biogas, anaerobic digestion, bioenergy

\section{Introduction}

Given the current technological developments, higher operation, and maintenance of new unconventional resources and potential reserves, it can be predicted that the availability of fossil fuels will not remain stable. The existing provision of the world's fossil fuels and oil

*e-mail: natalia_glowacka@interia.eu,glowacka@ei.sk decreases rapidly. The current consumption rate causes many ecological problems. Global warming and increases in of oil and petroleum product prices have caused a lack of energy safety, which is why researchers are currently focused on renewable energy from microalgae [1]. Microalgae have the potential to be a replacement for traditional crops (maize silage) due to rapid growth and high photosynthetic efficiency. The algae biomass can be cultivated in many different types of photobioreactors, raceways, or greenhouses. Microalgae are an integral part of the carbon cycle, which reduces greenhouse gas 
emissions. According to the climate data, in 2050, the concentration of $\mathrm{CO}_{2}$ in the atmosphere will reach up to 500 ppm. As examined by Tsai, microalgae were universally accepted as the ideal solution for monitoring greenhouse gas emissions. Research has shown the perfect uptake of $\mathrm{CO}_{2}$ (the amount of $159 \mathrm{mgL}^{-1}$ per day ${ }^{-1}$ with $93 \%$ of $\mathrm{CO}_{2}$ consumption efficiency) [2]. The understanding of algal taxonomy and ecology generally can lead us toward improving and enhancing environmental applications [3].

\section{Microalgae}

Microalgae are microscopic, photosynthetic organisms (prokaryotic or eukaryotic) specified as microorganisms that can adapt to a wide scale of environmental conditions because of their simple multicellular structure [4]. They are described as organisms with a very low demand for growing and increasing the growth rate. The main factors for controlling algae growth are: water, light, carbon dioxide, optimum temperature, and N:P:K ratio. For monitoring and optimizing algae growth, much higher productivity can be observed compared with conventional agricultural crops. During the exponential phase of growth, doubling of biomass in time less than 3.5 hours [5] can be noticed. Microscopic algae can consume and utilise waste $\mathrm{CO}_{2}$ (one kg dry of algal biomass utilises about $1.88 \mathrm{~kg}$ of $\mathrm{CO}_{2}$ ) [6]. Algal biomass consists of three main elements: carbohydrates, proteins, and natural oils (lipids) [7].

Microalgae can be considered as a suitable input material for the process of anaerobic digestion, due to their high biomass production and reduction of demand for arable land. One of the most significant factors that needs to be considered and that has an influence on the overall success of algae cultivation is choosing the appropriate and most effective algal strain [8]. The selection of a proper species of microalgae leads to the more effective formation of methane during the processing of biomass. One of the most essential and crucial parameters is the specific construction of cell wall of green microalgae, which determines the effectiveness of the anaerobic process [9]. It is usually recommended to use the method for disrupting the cell wall of the algae. Some species of algae do not have it in their morphological structure, and some types of microalgae have their cell wall made from proteins without cellulose or hemicellulose - polymers that play an essential part in easier degradability.

Together with the eligible selection of the proper microalgae strains for the process of the anaerobic digestion, it is also necessary to consider other parameters such as efficiency and sensitivity to biological contamination. When a selected microalgae strain has a strong structure of cell wall, there is a probability that biomass will not be able to be processed during anaerobic digestion. In this case, microalgae will have to be processed beforehand, using them as an input material in a biogas plant. The cell wall can be broken by the use of chemicals (solvents) or the process of sonification (sound waves).

Due to their high photosynthetic efficiency, green microalgae are being investigated as promising raw material for the production of fuels. The issue of cultivation of microalgae biomass has increased to the level of interesting biomaterial for researchers from all over the world [10].

The successful cultivation of microalgae requires knowledge of algal ecology to ensure the precise terms of growth in order to achieve a high concentration of biomass [11] (shown in Table 1). The microalgae biomass can be collected not only from the natural environment (water), but also from the artificial cultivation devices (raceway) or a photo bioreactor.

Green microalgae are one of the most promising sources for chlorophyll due to fact that cultivation of

Table 1. Elemental requirements for the cultivation of green microalgae.

\begin{tabular}{|c|c|c|}
\hline $\begin{array}{l}\text { Environmental factor/ } \\
\text { Parameter }\end{array}$ & Impact on microalgae cultivation & References \\
\hline Optimal light exposure & $\begin{array}{l}\text { Light/Dark cycle for microalgae: specific duration and frequency can influence } \\
\text { concentration of biomass and cell density as well as the content of fatty acids and protein. }\end{array}$ & {$[15]$} \\
\hline Temperature & $\begin{array}{l}\text { Each strain of microalgae requires different optimal temperatures and determines the } \\
\text { reaction of intracellular enzymes that affect the density of algae. When the intensity of } \\
\text { light changes, the temperature is the decisive parameter that influences microalgae growth. }\end{array}$ & {$[16]$} \\
\hline Elimination of oxygen & $\begin{array}{l}\text { Microalgae produce oxygen proportionally to their growth, which should be removed. } \\
\text { This refers to the activity of the } \mathrm{CO}_{2} \text {-fixing enzyme RuBisCO, which is involved in } \mathrm{CO}_{2} \\
\text { fixation to generate biomass, and which has an influence on the speed of photosynthesis, } \\
\text { exerting an influence on the concentration of biomass. }\end{array}$ & [17] \\
\hline $\mathrm{CO}_{2}$ supply & $\begin{array}{l}\text { The ability of microalgae to fix atmospheric or waste } \mathrm{CO}_{2} \text {, which is later allocated in } \\
\text { algal cells. The efficient capture of carbon dioxide is an essential part of the design of the } \\
\text { system for algae cultivation. }\end{array}$ & {$[18]$} \\
\hline $\mathrm{pH}$ control & $\begin{array}{c}\text { Controls the process of } \mathrm{CO}_{2} \text { supply, with each species of microalgae requesting different } \\
\text { optimal } \mathrm{pH} \text { values. }\end{array}$ & {$[19]$} \\
\hline $\begin{array}{l}\text { Circulation of the culture, } \\
\text { mixing }\end{array}$ & Affects the elimination of oxygen, distribution of light, and reduction of organic matter. & {$[20]$} \\
\hline
\end{tabular}


microalgae helps minimize the impact of global warming because of $\mathrm{CO}_{2}$ mitigation [12]. The rate of biofixation of $\mathrm{CO}_{2}$ by Chlorella sp. was tested and the results showed the values of $700 \mathrm{mg} \mathrm{L}^{-1} \mathrm{~d}^{-1}$ [6]. The tolerance of $\mathrm{CO}_{2}$ concentration can divide microalgae into two groups: sensitive to $\mathrm{CO}_{2}(2-5 \%)$ and tolerant of $\mathrm{CO}_{2}(5-20 \%)$ [13]. Green microalgae have an excellent capability to grow during the utilisation of high concentrations of $\mathrm{CO}_{2}$, which is why microalgae are perfect for the biofixation process [14].

\section{Anaerobic Digestion}

The process of anaerobic digestion (in biogas plant) is one of the best solutions of how to convert algae into bioenergy. With this process, it is possible to reach the biomethane content of about $250 \mathrm{~m}^{3} \mathrm{t}^{-1}$ of algae. Nevertheless, as defined by Ghasemi [21], there are two main difficulties involved with the digestion of algae biomass: low biodegradability due to strong structure of cell wall and high protein content with the consequence of the ammonia release (leading to toxicity) [22]. The precise assessment of the potential of the production of methane $\left(\mathrm{CH}_{4}\right)$ from algae was carried out by Matsui [23]. The commercial scale of a 4-stage anaerobic digester was used within the framework of this experiment. The daily input material consisted of 0.2 and 1.0 tons of algae (in the period of 15-25 days). The production of methane per ton of wet biomass was $22 \mathrm{~m}^{3}$ [24]. It was demonstrated by Mussgnug that the biogas potential heavily depends on the type of algal strain that will be the input material for the anaerobic digestion. The fermentation process of Chlamydomonas reinhardtii yielded the result of $587 \mathrm{ml}$ $( \pm 8.8 \mathrm{SE})$ of biogas production, while the fermentation process of Scenedesmus obliquus resulted only in $287 \mathrm{ml}$
$( \pm 10.1 \mathrm{SE})$ of produced biogas. The content of methane $\left(\mathrm{CH}_{4}\right)$ was $7-13 \%$ higher compared to the biogas from maize silage [25].

\section{Material and Methods}

The biotechnological process of obtaining biomass was performed with the use of the green algae genus Acutodesmus dimorphus (Turpin) P. Tsarenko cultivated in the laboratories of the Environmental Institute in Koš, Slovakia, on culture medium containing the source of N, P, and K. Bold's Basal medium [26] was used for the cultivation of microalgae.

The culture of Acutodesmus dimorphus (Turpin) P. Tsarenko was cultivated in a closed bioreactor with the working volume of $100 \mathrm{~L}$ in non-sterile conditions. The bioreactor was made of $0.2 \mathrm{~cm}$ plexiglass (produced by BioRent). A cool-white lamp was used for cultivating and maintaining the optimum temperature of $25-27^{\circ} \mathrm{C}$ (strongly influencing the cellular chemical composition). The proper $\mathrm{pH}$ level was kept between 7.0 and 7.3. The algae suspension was circulated in the bioreactor to provide access to the light for each algae cell. The circulation ( $\mathrm{CO}_{2}$ input) helped eliminate oxygen, which becomes toxic at high concentrations. The light exposure (ratio) required for the adequate photosynthetic activity was kept at 16:8 (light:dark). Biomass of microalgae was cultivated in a medium supplied with $\mathrm{CO}_{2}$. When the stationary phase of growth was reached, the cultures (samples) were collected (in a total amount of $4.7 \mathrm{~L}$ of microalgal slurry).

The realisation of the experiment of the comparative test of biogas yield of microalgal biomass was conducted in the experimental fermenter for batch tests (Fig. 1) in

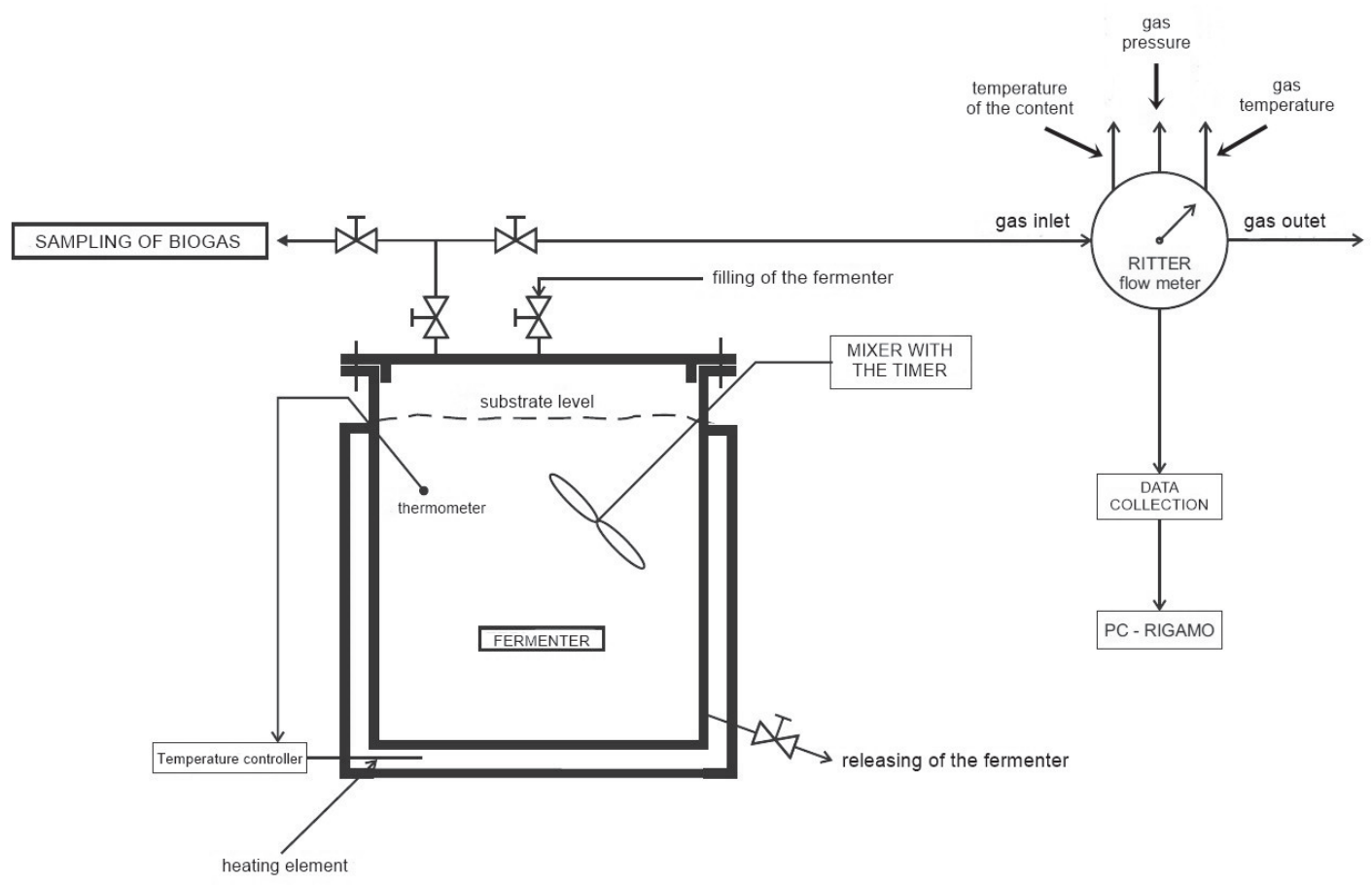

Fig. 1. Technological scheme of the $100 \mathrm{~L}$ experimental fermenter (author). 
the workplace of the Department of Regional Bioenergy in Kolínany (Slovak Republic). The fermenter has the following basic parameters: stainless steel tank with net volume of $100 \mathrm{~L}$, digital temperature control, electric water heating, and an electric low-speed mixer with the possibility of adjusting the mixing time and the breaks (12 cycles per day lasting from 20 to 30 minutes).

During the realisation of the experiment, the quantity of produced biogas was continuously measured and recorded through automatic recording (RIGAMO software). The fermenter was equipped with valves allowing for sampling of the substrate during the experiment for the implementation of chemical analysis as well as to analyse the composition of the produced biogas (Fig. 2). The experiment was carried out over a period of 30 days.

\section{Results and Discussion}

Acutodesmus dimorphus (Turpin) P. Tsarenko was chosen for this study and cultivated in laboratory conditions at a total amount of $4.7 \mathrm{~L}$ (characterisation of microalgae shown in Table 2). The fermenter was filled with the inoculum taken from the biogas plant in the volume of $97 \mathrm{~L}$, were the microalgae were added. The experiment was conducted in the period from 23 November 2016 until 23 December 2016. After closing the fermenter, it was set to auto mode control heating at $40^{\circ} \mathrm{C} \pm 1^{\circ} \mathrm{C}$, as well as the automatic recording mode of the cumulative biogas production. The value of biogas production was recorded every hour. The processed outputs of individual endpoints are shown in the following graphs. The cumulative production of biogas is

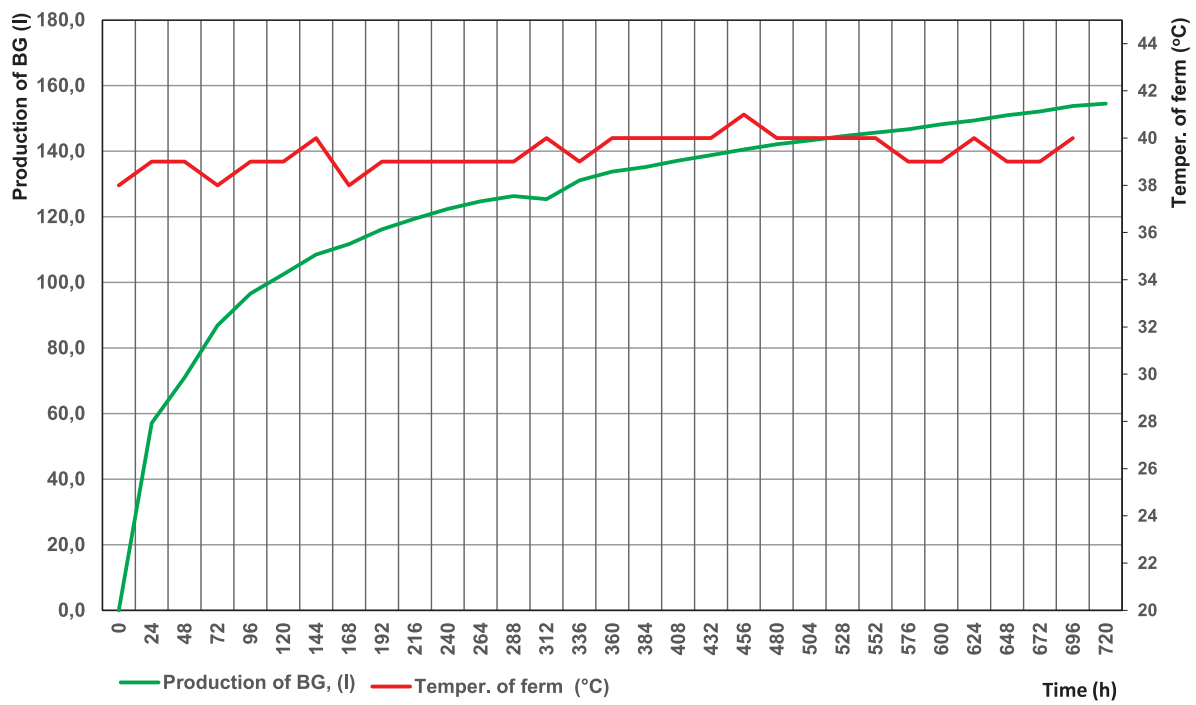

Fig. 2. Cumulative biogas production and the course of the temperature in the fermenter: $97 \mathrm{~L}$ inoculum with $4.7 \mathrm{~L}$ of algae (Acutodesmus dimorphus (Turpin) P. Tsarenko) (author).

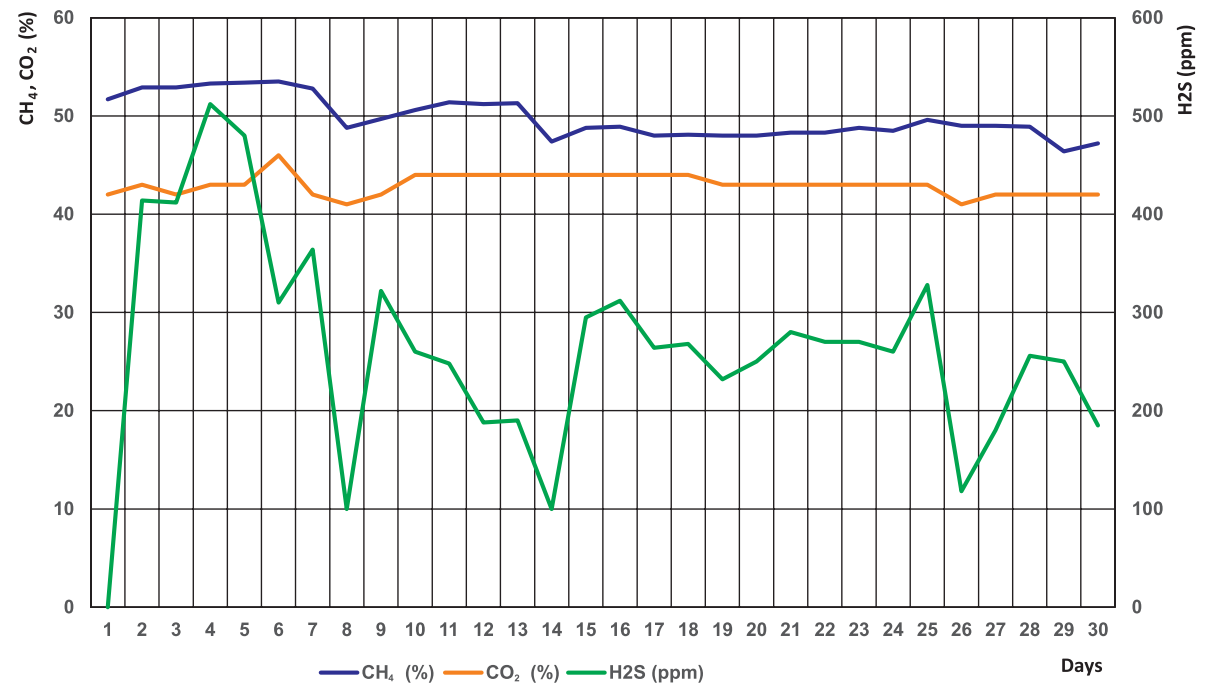

Fig. 3. The course of methane $\left(\mathrm{CH}_{4}\right)$, carbon dioxide $\left(\mathrm{CO}_{2}\right)$, and hydrogen sulphide $\left(\mathrm{H}_{2} \mathrm{~S}\right)$ in the biogas: $97 \mathrm{~L}$ inoculum with $4.7 \mathrm{~L}$ of algae (Acutodesmus dimorphus (Turpin) P. Tsarenko) (author). 
Table 2. Characterisation of microalgal slurry of Acutodesmus dimorphus (Turpin) P. Tsarenko (author).

\begin{tabular}{|c|c|c|c|c|c|c|c|}
\hline Parameter & $\begin{array}{c}\text { Temperature } \\
\left({ }^{\circ} \mathrm{C}\right)\end{array}$ & $\mathrm{pH}$ & $\mathrm{TS}(\%)$ & $\begin{array}{c}\mathrm{VS} \\
(\% \mathrm{TS})\end{array}$ & $\begin{array}{c}\mathrm{COD} \\
(\mathrm{mg} / \mathrm{L})\end{array}$ & $\begin{array}{c}\mathrm{N}_{\text {tot }} \\
(\mathrm{mg} / \mathrm{L})\end{array}$ & $\begin{array}{c}\mathrm{NH}_{4}^{+} \\
(\mathrm{mg} / \mathrm{L})\end{array}$ \\
\hline $\begin{array}{c}\text { Microalgae } \\
\text { Acutodesmus dimorphus (Turpin) } \\
\text { P. Tsarenko }\end{array}$ & 20 & 8.3 & 1.11 & 88.89 & 17000 & 102 & 50 \\
\hline
\end{tabular}

TS - dry matter, VS - organic dry matter, $\mathrm{COD}$ - chemical oxygen demand, $\mathrm{N}_{\text {tot }}$ - total nitrogen, $\mathrm{NH}_{4}^{+}$- ammonium ions

shown in the graph (Fig. 2). The total amount of biogas produced from the substrate in the fermenter during 3 0 days of experiment was $154.5 \mathrm{~L}$ of biogas, where the separated inoculum (97 L) produced $106.8 \mathrm{~L}$ of biogas. The composition of biogas is shown in the graph (Fig. 3).

The experiment confirmed that concentrated microalgae Acutodesmus dimorphus (Turpin) P. Tsarenko are a suitable feedstock for the process of anaerobic digestion. The results have shown the acceptable levels of methane content in biogas, which was 49.82 by volume and lower hydrogen sulfide values of $263.93 \mathrm{ppm}$. Thus, the biogas would be required prior to use in the cogeneration unit to go through the process of desulphurisation (to reach a value of less than $100 \mathrm{ppm}$ ).

In the period of 30 days of the experiment in the experimental fermenter, the total production of biogas (from Acutodesmus dimorphus (Turpin) P. Tsarenko) of $47.7 \mathrm{~L}$ was achieved, representing the average daily production of $1.59 \mathrm{~L} \cdot$ day $^{-1}$. The average $\mathrm{pH}$ in the fermenter was 6.80 and the temperature was $39.37^{\circ} \mathrm{C}$ throughout the duration of the experiment.

The content of dry matter (TS\%, DM) of the concentrated microalgae was $1.11 \%$, and the doses of dry matter (DM) and the organic dry matter (ODM) of microalgae in the fermenter were as follows:

Dose of DM $=0.05217 \mathrm{~kg}$ DM of microalgae

Dose of ODM $=0.04637 \mathrm{~kg}$ ODM of microalgae

The average total production of biogas (BP) per unit of dry matter of the biomass of microalgae was:

Biogas production $=0.9143 \mathrm{~m}^{3} / \mathrm{kg} \mathrm{DM}$

Biogas production $=1.0287 \mathrm{~m}^{3} / \mathrm{kg}$ ODM

For comparison, we include the results obtained during the same experiment using the $97 \mathrm{~L}$ of manure (composed of $80 \%$ of liquid pig manure, $20 \%$ of cattle manure). The results are shown in Table 3. The total production of biogas was $106.80 \mathrm{~L}$ of biogas, the calculated dry matter per unit of input material (dry matter content in the manure was $\mathrm{DM}=1.99 \%$ ) was obtained as the biogas production of $0.0553 \mathrm{~m}^{3} / \mathrm{kg}$ of DM with the composition of the average methane content of $47.95 \%$. Table 3 also shows the comparison of the biogas yield from maize silage and microalgae. The results show that the average biogas production per unit of TS (dry matter) was higher from Acutodesmus dimorphus (Turpin) P. Tsarenko $\left(0.9143 \mathrm{~m}^{3} / \mathrm{kg}\right)$ compared to maize silage.

\section{Conclusions}

Large-scale production of microalgal products (biomass, biofuel) encounters a number of technological issues and challenges that lead to problematic questions and unclear answers, mostly by economists [27]. The selection of a proper strain (genus) of microalgae, a suitable cultivation method, and selected culture conditions as well as the chemical composition have a huge influence on the costs of production and technology [28]. However, our research results have shown that the high methane yields $\left(0.9143 \mathrm{~m}^{3} / \mathrm{kg} \mathrm{DM}\right)$ obtained in the anaerobic digestion of Acutodesmus dimorphus (Turpin) P. Tsarenko predict that the use of microalgal biomass seems to be promising and has a huge prospect in the future of bioenergy. Moreover, biogas plants can provide free byproducts $\left(\mathrm{CO}_{2}\right)$ for the production and cultivation of green algae, which can in turn be used as a raw material in the process of anaerobic digestion. This application can bring us closer to the aspects of a circular economy.

Table 3. The average calculated values of the produced biogas and the composition of biogas (Microalgae Acutodesmus dimorphus (Turpin) P. Tsarenko, liquid manure, maize silage) (author).

\begin{tabular}{|c|c|c|c|c|c|c|}
\hline Input substrate & $\begin{array}{c}\text { Total } \\
\text { production } \\
\text { of BG } \\
(\mathrm{L})\end{array}$ & $\begin{array}{c}\text { Average } \\
\text { dose of DM } \\
(\mathrm{kg})\end{array}$ & $\begin{array}{c}\text { Average total } \\
\text { production of } \\
\text { BG per DM } \\
\left(\mathrm{m}^{3} / \mathrm{kg} \mathrm{DM}\right)\end{array}$ & $\begin{array}{c}\text { Average } \\
\text { methane } \\
\text { content } \\
(\text { Vol. } \%)\end{array}$ & $\begin{array}{c}\text { Average } \\
\text { carbon dioxide } \\
\text { content } \\
\text { (Vol. \%) }\end{array}$ & $\begin{array}{c}\text { Average content } \\
\text { of hydrogen } \\
\text { sulphide } \\
\text { (ppm) }\end{array}$ \\
\hline $\begin{array}{c}\text { Microalgae } \\
\text { Acutodesmus dimorphus } \\
\text { (Turpin) P. Tsarenko (4.7 L) }\end{array}$ & 47.70 & 0.0754 & $\mathbf{0 . 9 1 4 3}$ & 49.82 & 43.00 & 263.93 \\
\hline $\begin{array}{c}\text { Liquid manure (inoculum) } \\
\text { (97 L) }\end{array}$ & 106.80 & 1.93 & $\mathbf{0 . 0 5 5 3}$ & 47.95 & 39.86 & 107.21 \\
\hline Maize silage (3 kg) & 704.94 & 0.9876 & $\mathbf{0 . 7 1 3 8}$ & 53.98 & 40.40 & 315.17 \\
\hline
\end{tabular}

BG - biogas, DM - dry matter 


\section{Acknowledgements}

The authors wish to express their sincere thanks to the M. G. Kholodny Institute of Botany, NAS of Ukraine for providing the algal strain Acutodesmus dimorphus (Turpin) P. Tsarenko used in this study.

\section{References}

1. MOBIN S., ALAM F. Biofuel Production from Algae Utilizing Wastewater, 19th Australasian Fluid Mechanics Conference, Melbourne, Australia, 2014.

2. TSAI D.D.-W., CHEN P.H., RAMARAJ R. The potential of carbon dioxide capture and sequestration with algae, Ecological Engineering, Volume 98, 17, January 2017.

3. RAMANAN R., KIM B.-H., CHO D.-H., OH H.-M., KIM H.-S. Algae-bacteria interactions: Evolution, ecology and emerging applications, Biotechnology Advances, 34 (1), 14, 2016.

4. ABOMOHRA A. E.-F., JIN W., TU R., HAN S.-F., EID M., ELADEL H. Microalgal biomass production as a sustainable feedstock for biodiesel: Current status and perspectives, Renewable and Sustainable Energy Reviews 64 596, 2016.

5. KUMAR P., SHARMA P. K., SHARMA P. K., SHARMA D. Micro-algal Lipids: A Potential Source of Biodiesel, Journal of Innovations in Pharmaceuticals and Biological Sciences, 2 (2), 135, 2015.

6. ADAMCZYK M., LASEK J., SKAWIŃSKA A. $\mathrm{CO}_{2}$ biofixation and growth kinetics of Chlorella vulgaris and Nannochloropsis gaditana, Appl. Biochem. and Biotechnol., 179, 1248, 2016.

7. NELSON V., STARCHER K. Introduction to renewable energy second edition, CRC Press, 2015.

8. BRUTON T., LYONS H., LERAT Y., STANLEY M., RASMUSSEN M.B. A review of the potential of marine algae as a source of biofuel in Ireland. Dublin: Sustainable Energy Ireland; 88, 2009.

9. ABDEL-RAOUF N., AL-HOMAIDAN A. A., IBRAHEEM I. B. M. Microalgae and wastewater treatment, Saudi Journal of Biological Sciences, 19 (3), 257, 2012.

10. SARKAR O., AGARWAL M., KUMAR A. N., MOHAN S. V. Retrofitting hetrotrophically cultivated algae biomass as pyrolytic feedstock for biogas, bio-char and bio-oil production encompassing biorefinery. Bioresour. Technol. 178, 132, 2015.

11. BRENNAN L., OWENDE P. Biofuels from microalgae - A review of technologies for production, processing, and extractions of biofuels and co-products. Elsevier. doi:10.1016/j.rser.2009.10.009, 2009.

12. MIAZEK K, LEDAKOWICZ S. Chlorophyll extraction from leaves, needles and microalgae: a kinetic approach. Int J Agric Biol Eng. 6, 107, 2013.

13. MIYACHI S., IWASAKI I., SHIRAIWA Y. Historical perspective on microalgal and cyanobacterial acclimation to low- and extremely high- $\mathrm{CO}_{2}$ conditions, Photosynthesis Res 77, 139, 2003.
14. JI M.K., YUN H.S. HWANG J.H., SALAMA E.S., JEON B.H., CHOI J. Effect of flue gas $\mathrm{CO}_{2}$ on the growth, carbohydrate and fatty acid composition of a green microalga Scenedesmus obliquus for biofuel production, Environ. Technol., 1, 2016.

15. REN T. Primary Factors Affecting Growth of Microalgae Optimal Light Exposure Duration and Frequency, Graduate Theses and Dissertations, Paper 13793, 2014.

16. XIAO T., FANXIANG K., YANG Y., XIAOLI S., MIN Z. Effects of Enhanced Temperature on Algae Recruitment and Phytoplankton Community Succession. China Environmental Science 2009. 29 (6), 578, 2009.

17. LODISH H., BERK A., ZIPURSKY S. L., MATSUDAIRA P., BALTIMORE D., DARNELL J. Molecular Cell Biology, 4th edition, ISBN-10: 0-7167-3136-3, 2000.

18. KLINTHONG W., YANG Y.-H., HUANG C.-H., TAN C.-S. A Review: Microalgae and Their Applications in $\mathrm{CO}_{2}$ Capture and Renewable Energy, Aerosol and Air Quality Research, 15, 712, 2015.

19. YING K., GILMOUR D.J., ZIMMERMAN W.B. Effects of $\mathrm{CO}_{2}$ and $\mathrm{pH}$ on Growth of the Microalga Dunaliella salina, J Microb Biochem Technol 6, 167, 2014.

20. HAAS A., GREGG A. K., SMITH J. E., ABIERI M. L., HATAY M., ROHWER F. Visualization of oxygen distribution patterns caused by coral and algae, PeerJ. 2013; 1, e106, 2013

21. GHASEMI Y., RASOUL-AMINI S., NASERI A.T., MONTAZERI-NAJAFABADY N., MOBASHER M. A., DABBAGH F. Microalgae biofuel potentials (Review). Appl. Biochem. Microbiol 2012, 48, 126, 2012.

22. MURPHY F., DEVLIN G., DEVERELL R., MCDONNELL K. Biofuel production in ireland-an approach to 2020 targets with a focus on algal biomass, Energies, 6, (12), 6391, December 2013.

23. MATSUI J., AMANO T., KOIKE Y., SAIGANJI A., SAITO H. Methane Fermentation of Seaweed Biomass, American institute of chemical engineers, 2006.

24. ERTEM F.C., NEUBAUER P., JUNNE S. Environmental life cycle assessment of biogas production from marine macroalgal feedstock for the substitution of energy crops, Journal of Cleaner Production, 140 (2), 977, 2017.

25. MUSSGNUG J.H., KLASSEN V., SCHLUTER A., KRUSE O. Microalgae as substrates for fermentative biogas production in a combined biorefinery concept, Journal of Biotechnology 150, 51, 2010.

26. SHUKRI N.Z.M., ISMAIL H.N., CHAY T.C., JANI A.M.M. The Growth Performance of Freshwater Chlorella sp. and Scenedesmus sp. in Different Media, Journal of Applied Science and Agriculture, 9 (11) Special 2014, 119, 2014.

27. MORENO-GARCIA L., ADJALLE K., BARNABE S., RAGHAVAN G.S.V. Microalgae biomass production for a biorefinery system: Recent advances and the way towards sustainability, Renewable and Sustainable Energy Reviews, 76, 493, 2017.

28. PILOTO-RODRIGUEZ R., SANCHEZ-BORROTO Y., MELO-ESPINOSA E.A., VERHELST S. Assessment of diesel engine performance when fueled with biodiesel from algae and microalgae: An overview, Renewable and Sustainable Energy Reviews, 69, 833, 2017. 